\title{
Para-amino benzoic acid-mediated synthesis of vaterite phase of calcium carbonate
}

\author{
T N RAMESH*, S A INCHARA and K PALLAVI \\ Department of Studies and Research in Chemistry and Prof. C N R Rao Centre for Advanced Materials, \\ Tumkur University, Tumkur 572 103, India \\ e-mail: adityaramesh77@yahoo.com
}

MS received 24 July 2014; revised 25 November 2014; accepted 30 November 2014

\begin{abstract}
Calcium carbonate polymorphs were precipitated at room temperature and $80^{\circ} \mathrm{C}$ by varying the precipitation $\mathrm{pH}$, carbonate source, effect of solvent in presence and absence of structure directing agent such as para-aminobenzoic acid. Calcite phase of calcium carbonate was obtained when sodium hydrogen carbonate and/or sodium carbonate (used as precipitating agents) were added to calcium chloride solution at different $\mathrm{pHs}$ in water and/or methanol as solvent in separate experiments. Vaterite phase of calcium carbonate $\left(\mathrm{CaCO}_{3}\right)$ has been synthesized by mixing calcium chloride and sodium carbonate in presence of para-aminobenzoic acid when water-methanol binary mixture was used as solvent. Vaterite phase of calcium carbonate crystallizes in P63/mmc, while that of calcite phase in R-3mc, respectively. Calcite phase of calcium carbonate exhibits rhombohedral morphology, while vaterite phase has spherical morphology.
\end{abstract}

Keywords. Calcium carbonate; chemical synthesis; vaterite; polymorphism; X-ray diffraction; morphology.

\section{Introduction}

Calcium carbonate is one of the extensively studied model biominerals that exhibits rich polymorphism. ${ }^{1}$ Calcium carbonate crystallizes in different modifications, that is, amorphous calcium carbonate, calcium carbonate hydrate, calcium carbonate hexahydrate, calcite, aragonite and vaterite. ${ }^{2}$ Calcite is the thermodynamically stable modification and is present in sedimentary rocks in the form of limestone formed from shells of dead marine organisms. ${ }^{3}$ Molluskan shells, calcareous endoskeleton of worms and corals are the sources for the large-scale deposition of aragonite polymorph found on the seashores. ${ }^{4}$ Vaterite naturally occurs in tissues, gallstones and urinary calculi. Calcite and aragonite crystallizes in rhombohedral symmetry and has structural similarities in which the inter-planar carbonate ions are in the staggered arrangement relative to each other, thus minimizing electrostatic repulsion. In vaterite structure, the carbonate ions are relatively eclipsed to each other. ${ }^{5}$ Vaterite is a metastable phase similar to aragonite and has higher solubility than the other phases in water; hence, it is least stable. ${ }^{5}$ Vaterite on exposure to water will transform into calcite at ambient temperature or aragonite at high temperature. Aragonite will get readily converted to calcite in nature at higher temperature and transformation is more frequently observed

\footnotetext{
*For correspondence
}

than that of vaterite to calcite or to aragonite. The nucleation and growth of the three different polymorphs have been manipulated using crystal modifiers, biopolymers, inorganic salts, macromolecules, foreign ions and molecules (of both inorganic and organic nature). Some organic matter or inorganic metal ions may stabilize the vaterite and prevent its transformation into calcite or aragonite. ${ }^{6-9}$ Vaterite is the first solid phase precipitated during heterogeneous nucleation, and is spontaneously formed. Amino acids, peptides, proteins, biopolymers, carboxylate-rich carbonaceous material, lecithin, liposome, cetyl trimethyl ammonium bromide, polyvinyl alcohol, lipid membranes, polyvinyl alcohol, malonate, succinate, adipate and block polymers have been used to control the polymorphs and morphology of calcium carbonate. ${ }^{10-23}$ Glycine, L-alanine, aspartic acid and glutamic acid are used as directing agents in the synthesis of vaterite $\mathrm{CaCO}_{3} \cdot{ }^{24-32}$ Amino acids are amphoteric in nature, and at high $\mathrm{pH}$, functional groups such as carboxyl or amino groups are exposed, thus increasing the sorption of metal ions. Para-amino benzoic acid (PABA) is a naturally occurring compound, and is the primary active molecule on the organic/inorganic interface of biomineral tissue. PABA consists of benzene ring to which carboxylate and amino group functionalities are attached, which mimics the amino acid structure. PABA is slightly less soluble in water and can have similar functionality to that of amino acid during the nucleation and growth of metastable phases 
of calcium carbonate. Hence, we have used PABA for biomimetic growth of calcium carbonate.

In this article, we have demonstrated the role of PABA as an additive during mineralization of calcium carbonate polymorphs. Synthesis of vaterite phase of calcium carbonate at room temperature by precipitation using PABA as a directing agent in water, methanol and water-methanol mixture has been reported. Spherical morphology was observed for vaterite obtained using PABA in methanol-water mixture and rhombohedral morphology for calcite phase of calcium carbonate when water was used as a solvent at controlled $\mathrm{pH}$.

\section{Experimental}

\subsection{Reagents used}

Calcium chloride, sodium carbonate, sodium hydrogen carbonate, PABA and methanol were procured from SD Fine Chemicals, India, and used without purification.

To understand precipitation of different carbonate polymorphs, experiments were carried out by changing the concentrations of (i) calcium chloride, (ii) sodium hydrogen carbonate, (iii) sodium carbonate and (iv) PABA solutions in different solvents (water/methanol/ water-methanol binary mixture). The details of preparation conditions and concentration of solutions or reagents used are given in table 1.

In a typical experiment, calcium chloride was added to sodium carbonate and/or sodium hydrogen carbonate solution at RT and the precipitate obtained was aged in mother liquor at (i) room temperature, (ii) $80^{\circ} \mathrm{C}$ for $1 \mathrm{~h}$ separately, (iii) room temperature for $24 \mathrm{~h}$ and (iv) $80^{\circ} \mathrm{C}$ for $24 \mathrm{~h}$ separately.

About $100 \mathrm{~mL}$ distilled water $(\mathrm{pH} \mathrm{7})$ was taken in a $250 \mathrm{~mL}$ beaker to which different volumes of $(0.8 \mathrm{M})$ sodium carbonate solution ( $\mathrm{pH} 10)$ was added and stirred for $30 \mathrm{~min}$ at a constant rate, followed by addition of known volume of $(0.8 \mathrm{M})$ calcium chloride solution $(\mathrm{pH} 4)$. The solution was stirred for $1 \mathrm{~h}$ and during the process, milky white precipitate of calcium carbonate formed slowly. The $\mathrm{pH}$ of medium during precipitation was 6.0. Similar experiments were carried out at $\mathrm{pH} 7$, pH 8, pH 9 and $\mathrm{pH} 10$.

To investigate the effect of the solvent, calcium carbonate was prepared by following the procedure discussed in this section, in methanol solvent at $\mathrm{pH} 7$ and pH 9, respectively.

A known quantity of PABA (AR grade) was dissolved in water $(50 \mathrm{~mL})$. A $30 \mathrm{~mL}$ of $(0.8 \mathrm{M}) \mathrm{Na}_{2} \mathrm{CO}_{3}$ solution ( $\mathrm{pH} \mathrm{10)} \mathrm{solution} \mathrm{was} \mathrm{added} \mathrm{to} \mathrm{it} \mathrm{and} \mathrm{stirred}$ for $30 \mathrm{~min}$ at a constant rate, followed by addition of $30 \mathrm{~mL}$ of $(0.8 \mathrm{M})$ calcium chloride solution
$(\mathrm{pH} 4)$. The solution was stirred continuously for $1 \mathrm{~h}$, until slow precipitation of milky white $\mathrm{CaCO}_{3}$. The $\mathrm{pH}$ of medium during precipitation was 6.5 . By varying the volume of sodium carbonate/sodium hydrogen carbonate, the precipitation $\mathrm{pH}$ was tuned to $\mathrm{pH} 8 / \mathrm{pH} 9$.

The experiment mentioned in this section was also performed in methanol-water mixture at $\mathrm{pH} 7,8$ and 9.

\subsection{Characterization}

All the samples were characterized by powder X-ray diffraction (pXRD) using Bruker D8 advanced diffractometer $(\mathrm{CuK} \alpha$ source $\lambda=1.5418 \AA ; 30 \mathrm{~mA}$ and $40 \mathrm{kV}) .^{33,34}$ Data were collected at a scan rate of $2^{\circ} \mathrm{min}^{-1}$ with $2 \theta$ steps of $0.02^{\circ}$. Powder X-ray diffraction patterns were collected to identify the calcium carbonate polymorphs prepared at different experimental conditions reported in table 1 . Fourier transform infrared spectra were recorded using Bruker Alpha spectrometer (resolution $4 \mathrm{~cm}^{-1}$ ) to confirm the characteristic vibrational bands of different calcium carbonate polymorphs. Morphological features were recorded using scanning electron microscope (Jeol Model JM 6490 LV microscope).

\section{Results and Discussion}

Polymorphic modifications and particle morphology of calcium carbonate are dictated by the experimental conditions of precipitation such as temperature, $\mathrm{pH}$ of the medium, concentration ratio of the reactants, supersaturation, ionic strength or impurities. ${ }^{35-39}$ The crystal growth process of calcium carbonate was initiated at $\mathrm{pH}$ $6.0, \mathrm{pH} 7.0$ and $\mathrm{pH} 8.0$ by mixing appropriate quantities of calcium chloride, sodium carbonate and/or sodium hydrogen carbonate solutions using water as solvent. In the conditions mentioned above, the calcite phase of calcium carbonate was obtained (figures S1-S6).

\subsection{Sodium hydrogen carbonate as source and water as solvent}

The formation process of calcium carbonate can be predicted based on the carbonate source used as a precursor.

$$
\begin{gathered}
\mathrm{CaCl}_{2}+\mathrm{NaHCO}_{3} \rightarrow \mathrm{CaCO}_{3}+\mathrm{NaCl}+\mathrm{HCl} \\
\mathrm{HCO}_{3-} \leftrightarrow \mathrm{H}^{+}+\mathrm{CO}_{3}^{2-} \\
\mathrm{Ca}^{2+}+\mathrm{CO}_{3}^{2-} \leftrightarrow \mathrm{CaCO}_{3}
\end{gathered}
$$

or

$$
\mathrm{CaCl}_{2}+\mathrm{Na}_{2} \mathrm{CO}_{3} \rightarrow \mathrm{CaCO}_{3}+2 \mathrm{NaCl}
$$


Table 1. Experimental conditions and concentration of solutions or reagents used to prepare calcium carbonate polymorphs.

\begin{tabular}{|c|c|c|c|c|c|c|c|c|c|c|c|c|c|c|}
\hline & & & Reagent & & & & & & olvents & & & $\mathrm{pH}$ & Room Temp & Phase \\
\hline & $\mathrm{CaCl}_{2}$ & & $\mathrm{Na}_{2} \mathrm{CO}$ & & $\mathrm{NaHCO}$ & & PABA & $(0.8 \mathrm{M})$ & $\mathrm{H}_{2} \mathrm{O}+\mathrm{MeOH}$ & $\mathrm{MeOH}$ & $\mathrm{H}_{2} \mathrm{O}+$ & & aged for & \\
\hline & Concentration & $\begin{array}{l}\text { Volume } \\
(\mathrm{mL})\end{array}$ & Concentration & $\begin{array}{l}\text { Volume } \\
\text { (mL) }\end{array}$ & Concentration & $\begin{array}{l}\text { Volume } \\
(\mathrm{mL})\end{array}$ & $\begin{array}{l}\mathrm{H}_{2} \mathrm{O} \text { volume } \\
(\mathrm{mL})\end{array}$ & $\begin{array}{c}50 \% \mathrm{H}_{2} \mathrm{O} \\
50 \% \mathrm{MeOH} \\
(\mathrm{v} / \mathrm{v} \%)\end{array}$ & $(\mathrm{v} / \mathrm{v} \%)$ & (v) (mL) & (v) $(\mathrm{mL})$ & & & \\
\hline 1 & & & & & & & & & & & & & RT-1 h & Calcite \\
\hline 2 & & & & & & & & & & & & & RT-24 h & Calcite \\
\hline 3 & & & & & & & & & & & & & $80^{\circ} \mathrm{C}-1 \mathrm{~h}$ & Calcite \\
\hline 4 & $1.0 \mathrm{M}$ & 100 & $1.0 \mathrm{M}$ & 100 & & & & & & & & & $80^{\circ} \mathrm{C}-24 \mathrm{~h}$ & $\begin{array}{c}\text { Calcite+ } \\
\text { vaterite+ } \\
\text { aragonite }\end{array}$ \\
\hline 5 & & & & & & & & & & & & & RT-1 h & Calcite \\
\hline 6 & & & & & & & & & & & & & RT-24 h & Calcite \\
\hline 7 & $1.0 \mathrm{M}$ & 100 & & & $1.0 \mathrm{M}$ & 100 & & & & & & & $80^{\circ} \mathrm{C}-1 \mathrm{~h}$ & Calcite \\
\hline 8 & & & & & & & & & & & & & $80^{\circ} \mathrm{C}-24 \mathrm{~h}$ & Calcite \\
\hline 9 & & 30 & & & & & & & & & & 6 & & Calcite \\
\hline 10 & $0.8 \mathrm{M}$ & 100 & $0.8 \mathrm{M}$ & 30 & & & & & & & & 7 & & Calcite \\
\hline 11 & & 65 & & 35 & & & & & & & 100 & 8 & $1 \mathrm{~h}$ & Calcite \\
\hline 12 & & & & 60 & & & & & & & & 10 & & Calcite \\
\hline 13 & $0.8 \mathrm{M}$ & 30 & $0.8 \mathrm{M}$ & 40 & & & & & & & & 6 & & Calcite \\
\hline 14 & & & & 60 & $0.8 \mathrm{M}$ & 30 & & & & & 100 & 7 & $1 \mathrm{~h}$ & Calcite \\
\hline 15 & & & & 80 & & & & & & & & 8 & & Calcite \\
\hline 16 & & & & 30 & & & & & & $100 \mathrm{ml}$ & & 5 & & Calcite \\
\hline 17 & & & & 60 & & & & & & & & 9 & & Calcite \\
\hline 18 & $0.8 \mathrm{M}$ & 30 & $0.8 \mathrm{M}$ & 30 & & & & & $100 \mathrm{ml}$ & & & 6.5 & $1 \mathrm{~h}$ & $\begin{array}{l}\text { Calcite+ } \\
\text { vaterite }\end{array}$ \\
\hline 19 & & & & 60 & & & & & & & & 10 & & $\begin{array}{l}\text { Calcite+ } \\
\text { vaterite }\end{array}$ \\
\hline 20 & $0.8 \mathrm{M}$ & 30 & $0.8 \mathrm{M}$ & 60 & & & & & $\begin{array}{c}50 \mathrm{ml} \mathrm{H}{ }_{2} \mathrm{O}+ \\
50 \mathrm{ml} \mathrm{MeOH}\end{array}$ & & & 10 & $1 \mathrm{~h}$ & $\begin{array}{l}\text { Phase could not } \\
\text { be identified }\end{array}$ \\
\hline 21 & & 50 & & 50 & & & & & & & & 7 & & Calcite \\
\hline 22 & $0.0728 \mathrm{M}$ & & $0.0728 \mathrm{M}$ & 55 & & & $\begin{array}{c}100 \mathrm{~cm}^{3} \\
(0.0364 \mathrm{M})\end{array}$ & & & & & 8 & $1 \mathrm{~h}$ & Calcite \\
\hline 23 & & 25 & & 75 & & & & & & & & 9 & & Calcite \\
\hline 24 & & 30 & & 30 & & & & $50 \mathrm{~cm}^{3} \mathrm{H}_{2} \mathrm{O}+$ & & & & 6 & & $\begin{array}{c}\text { Phase could not } \\
\text { be identified }\end{array}$ \\
\hline $\begin{array}{l}25 \\
26\end{array}$ & $0.8 \mathrm{M}$ & 40 & $0.8 \mathrm{M}$ & 75 & & & & $80 \mathrm{~cm}^{3} \mathrm{MeOH}$ & & & & $\begin{array}{l}8 \\
9\end{array}$ & $1 \mathrm{~h}$ & $\begin{array}{l}\text { vaterite } \\
\text { vaterite }\end{array}$ \\
\hline 27 & & 30 & & 60 & & & & & & & & 10 & & $\begin{array}{c}\text { Vaterite+unknown } \\
\text { peaks (tiny) }\end{array}$ \\
\hline
\end{tabular}


Calcium carbonate samples were obtained by the addition of calcium chloride in water to sodium hydrogen carbonate solution at ambient temperature and at higher temperature $\left(80^{\circ} \mathrm{C}\right)$ and aged for $1 \mathrm{~h}$ and $24 \mathrm{~h}$ separately.

In addition, sodium hydrogen carbonate solution was added to calcium chloride in water at ambient temperature and the precipitates were aged for $1 \mathrm{~h}$ at $\mathrm{pH} 6$, 7 and 8 separately (table 1). In the conditions mentioned above, rhomboheral phases of calcium carbonate samples (calcite) were obtained (figures S1-S3).

\subsection{Sodium carbonate as source and water as solvent}

Calcium carbonate was obtained by the addition of calcium chloride to sodium carbonate at ambient temperature and higher temperature $\left(80^{\circ} \mathrm{C}\right)$ and the precipitates were aged for $1 \mathrm{~h}$ and $24 \mathrm{~h}$ separately. In both the conditions, calcite phase of calcium carbonate was obtained. The reflections in the powder X-ray diffraction patterns of calcite phases obtained in the above methods match with the peaks reported in ICSD 18127 containing calcite phase of calcium carbonate (figures S4-S6). The peaks were observed at $23.09^{\circ}, 29.40^{\circ}$, $36.00^{\circ}, 39.45^{\circ}, 43.22^{\circ}, 47.12^{\circ}, 47.54^{\circ}, 48.50^{\circ}$, respectively, and have been indexed to (012), $(-114),(-120)$, $(-123),(-222),(024),(018)$ and $(-126)$ planes. The lattice parameters of calcite phase of calcium carbonate is $a=b=4.9908 \AA ; c=17.10569 \AA, \alpha=\beta=90^{\circ}$ and $\gamma=120^{\circ}$.

\subsection{Effect of solvent (methanol) and sodium hydrogen carbonate-sodium carbonate source}

To examine the effect of solvent, calcium carbonate was precipitated by mixing calcium chloride and sodium carbonate and sodium hydrogen carbonate mixtures at different volume ratios to attain $\mathrm{pH} 5$ and $\mathrm{pH} 9$ separately in methanol. At $\mathrm{pH} 5$, pure calcite phase of calcium carbonate was obtained, while at $\mathrm{pH} 9$ and above, the pXRD patterns could not be indexed to calcite, aragonite and vaterite phases of calcium carbonate (figures S7 and S8).

\subsection{Effect of para-amino benzoic acid as structure directing agent}

The bifunctional nature of PABA plays an important role in precipitating calcium carbonate polymorphs. At $\mathrm{pH}<7$, PABA possesses charge on $\mathrm{NH}_{3}^{+}-\mathrm{C}_{6} \mathrm{H}_{4}-\mathrm{COOH}$ and cannot interact with $\mathrm{Ca}^{2+}$ ions. Hence, $\mathrm{Ca}^{2+}$ reacts directly with carbonate ion, thus calcite phase readily forms. At $\mathrm{pH} 8$, carboxylate group of PABA and $\mathrm{CO}_{3}^{2-}$ compete towards binding to $\mathrm{Ca}^{2+}$ ion in water and in methanol-water mixture as solvent.

When calcium chloride was added to sodium carbonate and PABA solution in aqueous medium $\left(\mathrm{H}_{2} \mathrm{O}\right)$ at $\mathrm{pH}$ 6, calcite was a major phase and aragonite was the minor phase at $\mathrm{pH} 6$. When calcium chloride solution was slowly added to attain a desired $\mathrm{pH}>7$, (i.e. $\mathrm{pH} 7$ and $\mathrm{pH} 8$ separately) carbonate and carboxylate groups present in the solution can compete towards binding to calcium ions. At $\mathrm{pH}>7$, we get calcite as minor phase and vaterite as major phase with impurities (figures S9 and S11). To prepare a single phase of vaterite, the polarity of the solvent medium was lowered by using water-methanol mixture. Also, at each $\mathrm{pH}$, the growth process of calcium carbonate was further compared in the presence of PABA in water and also PABA in water-methanol mixture separately. In the absence of PABA in water/PABA in water-methanol mixture, thermodynamically stable phase of calcite was observed. When the solution $\mathrm{pH}$ was 6.0 or 7.0 in the presence and absence of PABA in water/water-methanol mixture, rhombohedral calcite phase along with vaterite phases was observed (figure S10). Figure 1 shows the pXRD pattern of the product obtained using calcium chloride, sodium hydrogen carbonate, sodium carbonate, PABA in water-methanol mixture at $\mathrm{pH} 8$. At $\mathrm{pH}$ 8 , in the presence of PABA in water-methanol mixture, we observe pure vaterite phase. The peaks in the powder $\mathrm{X}$-ray diffraction patterns observed in figure 1 could be indexed to vaterite phase of calcium carbonate (JCPDF: 33-0268) with the space group P63/mmc. The lattice parameters for the observed powder X-ray diffraction pattern of vaterite phase $(a=b=4.1303 \AA$ A c $=8.478$ $\AA, \alpha=\beta=90^{\circ}$ and $\gamma=120^{\circ}$ ) matches with the literature reports ${ }^{33}$ and the reflections have been indexed to (110), (112), (114), (300) planes.

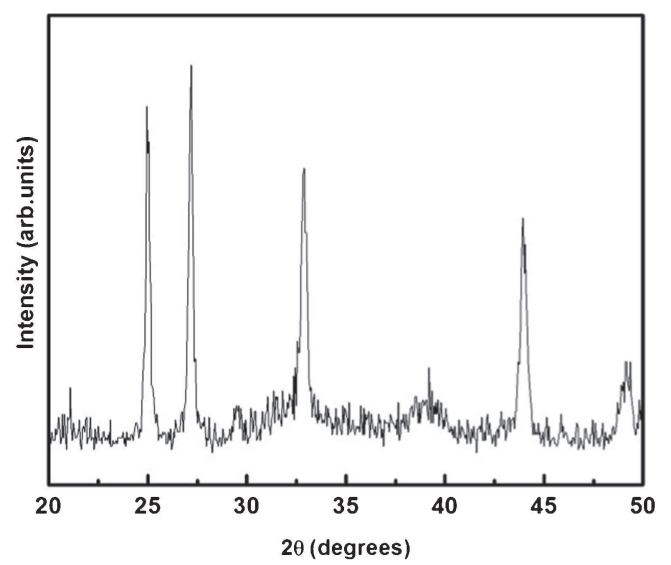

Figure 1. pXRD pattern of the calcium carbonate samples obtained by the addition of calcium chloride to sodium carbonate solutions at $\mathrm{pH} 8$ (water-methanol mixture as solvent) ambient temperature - aged for $1 \mathrm{~h}$ (vaterite phase). 
Table 2. Vibrational frequencies of calcium carbonate polymorphs (experimental data).

\begin{tabular}{lccl}
\hline Type & Calcite & Vaterite & $\begin{array}{l}\text { Nature of fundamental } \\
\text { vibration }\end{array}$ \\
\hline$\nu 3$ & 1433.8 & 1471 & Anti-symmetric stretch \\
$\nu 1$ & - & 1180 & \\
& & 1087 & Symmetric stretch \\
$\nu 2$ & 876 & 1077 & \\
& & 876 & Out-of-plane bending \\
$\nu 4$ & 746.3 & 790 & (doubly degenerate) \\
$\nu 4$ & 712 & 745 & degenerate) \\
\hline
\end{tabular}

There will be significant variations in the infraredactive vibrations of calcite and vaterite phases of calcium carbonate and these vibrations occur in the fingerprint region. Infrared spectral data of calcite and vaterite phases of calcium carbonate are shown in table 2 . In pure calcite, characteristic carbonate ions at $1417 \mathrm{~cm}^{-1}$; C-O stretching at $1084 \mathrm{~cm}^{-1}$ and at $713 \mathrm{~cm}^{-1}$ were observed. In the vaterite phase of calcium carbonate, characteristic $\mathrm{CO}_{3}^{2-}$ at $1417 \mathrm{~cm}^{-1}$, splits into $1478 \mathrm{~cm}^{-1}$ and $1406 \mathrm{~cm}^{-1}, \mathrm{C}-\mathrm{O}$ stretching appears at $744 \mathrm{~cm}^{-1}$. In the vaterite phase the peak at 1084 and $671 \mathrm{~cm}^{-1}$ are more prominent than that in calcite. ${ }^{34,40}$ In table 2 , the vibrational frequencies exhibited by the calcite and vaterite phases of calcium carbonate samples.

Figure 2 shows the scanning electron micrographs of calcite phase of calcium carbonate obtained by mixing sodium carbonate, calcium chloride solutions and the morphology is of rhombohedral in nature. Scanning electron micrograph of vaterite phase of calcium carbonate obtained when sodium carbonate, calcium chloride and PABA were used in methanol-water mixture and the shape is spherical (figure 2, right).

Interesting transitions in the crystal morphology and phases were observed in the experiments carried out at different $\mathrm{pHs}$ using different precipitating agents such as sodium carbonate/sodium hydrogen carbonate and

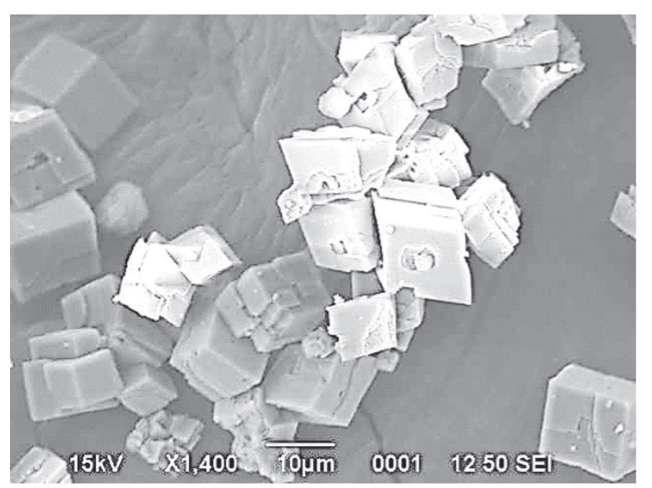

structure directing agents such as PABA in different solvent media.

\section{Conclusion}

The local supersaturation in which nucleation and growth takes place plays an important role in controlling the vaterite phase in PABA (water-methanol mixture) environment. Precipitation $\mathrm{pH}$ and the solvent medium should be delicately controlled; otherwise, a mixture of different forms of calcite, aragonite and vaterite phases of calcium carbonate will be obtained. Hence, formation of calcium carbonate in different molar ratio of $\mathrm{Ca}^{2+} / \mathrm{CO}_{3}^{2-}$ at room temperature will generate calcite phase. Water-methanol binary mixture was used to prepare and maintain the stability of vaterite phase. Precipitation of vaterite phase of calcium carbonate occurs under ambient condition using PABA, which mimics the behaviour of amino acids at room temperature. PABA exhibits chemical properties similar to that of amino acids, thus providing an alternative source for amino acid usage in crystal engineering and biomineralization process to prepare functionally important metastable phases of inorganic materials.

\section{Supplementary Information}

Supplementary data of the powder X-ray diffraction patterns and scanning electron micrograph of calcium carbonate obtained at different experimental conditions are available at www.ias.ac.in/chemsci.

\section{Acknowledgements}

Authors gratefully thank Tumkur University for support and facilities. TNR express his deepest gratitude to Prof. P Vishnu Kamath, Department of Chemistry,

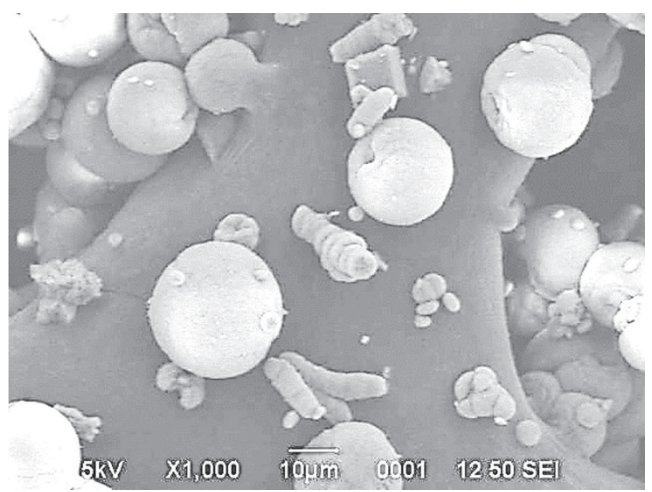

Figure 2. Scanning electron micrographs of calcite phase (left) and vaterite phase (right) of calcium carbonate. 
Bangalore University for extending unconditional support and providing lab facilities. Authors also thank Supreeth Nagendran, Shivanna and Kiran, Department of Chemistry, Bangalore University for their help in recording X-ray diffraction data and electron microscopic images.

\section{References}

1. Mann S 2001 In Biomineralisation Principles and Concepts in Bioinorganic Materials Chemistry (UK: Oxford University Press)

2. Meldrum F C 2003 Inter. Mater. Rev. 48187

3. King C 1878 In U.S. Geological exploration of the fortieth parallel (Washington: U.S. Government) p. 1

4. Weiss I M, Tuross N, Addadi L and Weiner S $2002 \mathrm{~J}$. Exp. Zool. 293478

5. Wells A F 1945 Structural Inorganic Chemistry $4^{\text {th }}$ Edition (UK: Oxford University Press) p. 1075

6. Albright J N 1969 Amer. Miner. 56269

7. Nonrnwooo D O, Nl Q and Lnwrs D 1969 Amer. Mineral. $\mathbf{5 3} 2089$

8. Ries J B, Anderson M A and Hill R T 2008 Geobiology 6106

9. Ogino T, Suzuki T, Sawada K and Geochim 1987 Cosmochim. Acta $\mathbf{5 1} 2757$

10. Chakrabarty D and Mahapatra S 1999 J. Mater. Chem. 9 2953

11. Nassif N, Gehrke N, Pinna N, Shirshova N, Tauer K, Antonietti M and Cölfen H 2005 Angew. Chem., Int. Ed. 446004

12. Belcher A M, Wu X H, Christensen R J, Hansma P K, Stucky G D and Morse D E 1996 Nature 38156

13. Kim S and Park C B 2010 Langmuir 2614730

14. Takiguchi M, Igarashi K, Azuma M and Ooshima $\mathrm{H}$ 2006 Cryst. Growth Des. 62754

15. Lin Y, Hu Q, Chen J, Ji J and Teng H H 2009 Cryst. Growth Des. 94634

16. Choi K M and Kuroda K 2012 Cryst. Growth Des. 12 887

17. Jin D, Wang F and Yue L 2011 Cryst. Res. Technol. 46 140
18. Naka K, Huang S C and Chujo Y 2006 Langmuir 22 7760

19. Cai A, Xu X, Pan H, Tao J, Liu R, Tang R and Cho K 2008 J. Phys. Chem. 11211324

20. Hosoda N, Sugawara A and Kato T 2003 Macromolecules 366449

21. Wang T, Leng B, Che R and Shao Z 2010 Langmuir 26 13385

22. Kuther J, Seshadri R, Knoll W and Tremel W 1998 J. Mater. Chem. 8641

23. Sarkar A, Dutta K and Mahapatra S 2013 Cryst. Growth Des. 13204

24. Hou W and Feng Q 2006 Mater. Sci. Eng. 26644

25. Raz S, Hamilton P C, Wilt F H, Weiner S and Addadi L 2003 Adv. Funct. Mater. 13480

26. Matahwa H, Ramiah V and Sanderson R D 2008 J. Cry. Growth 3104561

27. Butler M F, Glaser N, Weaver A C, Kirkland M and Butler M H 2006 Cryst. Growth Des. 6781

28. Kirboga S and Oner M 2013 Cryst Eng. Comm. 15 3678

29. Manoli F and Dalas E 2001 J. Crystal Growth 222293

30. Leiserowitz L, Jacquemain D, Wolf S G, Leveiller F, Deutsch M, Kjaer K, Als-Nielsen J and Lahav M 1992 Angew. Chem. 104134

31. Ries J B, Anderson M A and Hill R T 2008 Geobiology 6106

32. Weiner S and Addadi L 1997 J. Mater. Chem. 7689

33. Shivkumara C, Singh P, Gupta A and Hegde M S 2006 Mater. Res. Bull. 411455

34. Nakamoto K 2009 In Infrared and Raman Spectra of Inorganic and Coordination Compounds: Part B, Applications in Coordination, Organometallic and Bioinorganic Chemistry $5^{\text {th }}$ Edition (US: John Wiley)

35. Weiss I M, Tuross N, Addadi L and Weiner S $2002 \mathrm{~J}$. Exp. Zool. 293478

36. Wells A F 1945 In Structural inorganic chemistry $4^{\text {th }}$ Edition (UK: Oxford University Press)

37. Albright J N 1969 Amer. Miner. 56269

38. Nonrnwooo D O, Nl Q and Lnwrs D 1969 Amer. Mineral. 532089

39. Ries J B, Anderson M A and Hill R T 2008 Geobiology 6106

40. Louisfert J and Pobbequin T 1952 C. R. 235287 